DOI: 10.34015/2523-4552.2021.3.02

УДК 343.1

\author{
Муляр Г. В., \\ доктор юридичних наук, доцент, \\ професор кафедри кримінального \\ права, процесу та криміналістики \\ Академії праці, соціальних відносин $і$ \\ туризму \\ ORCID: 0000-0003-2636-0509
}

Ховпун О. C., доктор юридичних наук, доцент, завідувач кафедри кримінального права, процесу та криміналістики Академії праці, соціальних відносин $і$ туризму ORCID: 0000-0002-5753-966X

\section{Бегма А. П.,} кандидат юридичних наук, доцент кафедри кримінального права, процесу та криміналістики Академії праці, соціальних відносин і туризму ORCID: 0000-0003-3009-2850

\title{
ОСОБЛИВОСТІ ПРИТЯГНЕННЯ ОСІБ ДО КРИМІНАЛЬНОЇ ВІДПОВІДАЛЬНОСТІ В ІНФОРМАЦІЙНІЙ СФЕРІ
}

У статті розглянуто окремі проблемні питання притягнення осіб до кримінальної відповідальності за вчинення інформаційних правопорушень. Досліджено визначення таких термінів як інформаційне правопорушення, інформаційна відповідальність. Зазначено, що до законодавства доцільно внести нові терміни щодо правопорушень в інформаційній сфері: кіберпростір, кібертероризм, кіберекстремизм, кібервійни, кіберзлочин, кіберзлочинність та надати їм визначення.

Ключові слова: інформаційне правопорушення; інформаційно-правова відповідальність; кіберзлочинність.

В статье рассмотрены отдельные проблемные вопросы привлечения лиц к уголовной ответственности за совершение информационных правонарушений. Исследованы определения таких терминов как информационное правонарушение, информационная ответственность. Отмечено, что в законодательство целесообразно внести новые термины правонарушений в информационной сфере: киберпространство, кибертерроризм, киберэкстремизм, кибервойны, киберпреступление, киберпреступность и дать им определение.

Ключевые слова: информационное правонарушение; информационноправовая ответственность; киберпреступность. 
Постановка проблеми. Правопорушенням в інформаційній сфері приділяють окрему увагу, оскільки 3 кожним днем інформаційні технології впроваджуються у сфери суспільного життя громадян. Можливість користування ресурсами у мережі Інтернет передбачають надання персональної інформації для загального користування, при цьому, не враховуючи, що зазначені дані можуть використовуватись у неправомірних цілях. Слід приділяти особливу увагу захисту інформації, встановлювати обмеження на їі розповсюдження, контролювати можливі втручання.

Інформаційне правопорушення - це протиправне діяння конкретного суб'єкта, що здійснює замах на інформаційний правопорядок і заподіює шкоду інформаційній сфері. Відповідальність за інформаційне правопорушення може відрізнятись в залежності від заподіяної шкоди та може носити дисциплінарний, адміністративний чи кримінальний характер скоєння. В свою чергу, притягнення до кримінальної відповідальності передбачає скоєння діяння, яке містить усі ознаки кримінального правопорушення, посягає на відносини у інформаційній сфері та наносить різного роду збитки.

Постановка завдання. Метою дослідження $\epsilon$ встановлення видів відповідальності за вчинення правопорушень в інформаційній сфері. Серед основних завдань слід виділити: дослідження поняття "інформаційне правопорушення" та його ознак на основі теоретичних досліджень науковців; аналіз впровадження нового виду відповідальності - інформаційно-правової; мож- ливість створення Інформаційного кодексу.

Аналіз останніх досліджень і публікацій. Проблемі правового регулювання притягнення осіб до кримінальної відповідальності в інформаційній сфері присвячені наукові праці таких дослідників, як А. О. Волкова, Л. П. Коваленко, О. Косиця, Д. О. Маріц, І. А. Пахомова, Г. М. Писаренко, О. М. Селезньова, 0.О.Тихомиров та інші. Однак окремі аспекти правового регулювання все ще недостатньо висвітлені або вимагають додаткового дослідження, оскільки з розвитком інформаційних технологій такий різновид правопорушень зустрічається частіше та в нових формах вчинення.

Виклад основного матеріалу. Конституція України містить закріплене положення про можливість доступу до інформації, яке відображається у ст. 34, а саме: право кожного на свободу думки й слова, на вільне вираження своїх поглядів і переконань; право вільно збирати, зберігати, використовувати й поширювати інформацію усно, письмово або в інший спосіб на свій вибір [1]. Основний Закон країни розкриває широкі можливості для вільного володіння, користування та розпорядження інформацією, в тому числі захисту інформації кожної людини. Таке твердження надає не тільки спектр дій для громадян, які вчиняють дії з інформацією, але й розширює поле для діяльності зловмисників, які використовують таку інформацію для своїх цілей.

Законом України "Про доступ до публічної інформації” передбачено, що інформація потребує додаткового захисту від несанкціонованих втручань. Передбачено, що кожна 
особа має право: знати у період збирання інформації, але до початку її використання, які відомості про неї та з якою метою збираються, як, ким і 3 якою метою вони використовуються, передаються чи поширюються, крім випадків, встановлених законом (п. 1 ст. 10); доступу до інформації про неї, яка збирається та зберігається (п. 2 ст. 10) [2].

Доцільно вказати, що інформація потребує додаткового захисту від несанкціонованих втручань, законодавством визначена пряма заборона вчинення незаконних дій 3 інформацією. Громадянам, в свою чергу, надана можливість відновлення порушених прав. Доступність інформації $\epsilon$ важливим аспектом розвитку демократичної держави, але її захист має не менш актуальне значення.

Стратегія розвитку інформаційного суспільства в Україні визначила основні принципи інформаційного суспільства, серед яких: правомірності одержання, використання, поширення, зберігання та захисту інформації; забезпечення інформаційної безпеки. В свою чергу, Стратегія визначила серед завдань: повномасштабне входження України до глобального інформаційного простору; впровадження новітніх інформаційно- комунікаційних технологій в усі сфери суспільного життя, діяльність державних органів та органів місцевого самоврядування, у тому числі в процесі реалізації Ініціативи "Партнерство "Відкритий уряд" та електронного урядування [3]. Стратегія має на меті полегшення питань для громадян, пов'язаних з інформацією, запровадження нових інформаційних технологій, в тому числі в органи державної влади.
Захист інформації є важливим завданням національної безпеки держави, оскільки місце і роль будьякої держави у міжнародному співтоваристві пов'язані з їі здатністю продукувати, споживати і використовувати нові знання й технології. Інформація являє собою своєрідну соціальну зброю, породжує проблеми захисту інформаційних ресурсів та інформації у сфері її обігу.

Інформаційним правопорушенням визнається протиправна, винна (умисна або необережна) дія чи бездіяльність конкретного суб'єкта, що здійснює замах на встановлений інформаційний правопорядок i заподіює шкоду інформаційній сфері або створює реальну загрозу такого спричинення і за яку законом передбачено юридичну відповідальність [4, с. 85].

Ми погоджуємось, що інформаційне правопорушення заподіює шкоду інформаційній сфері, але потрібно зазначити, що шкода заподіюється в тому числі фізичним та юридичним особам та порушує встановлений порядок функціонування інформаційних систем.

Наукова стаття “Особливості юридичної відповідальності за правопорушення в інформаційній сфері" (2014 р.), яка належить авторству А. О. Волкової розкриває питання юридичної відповідальності за інформаційні правопорушення. Фактично сформоване законодавство щодо попередження та припинення правопорушень в інформаційній сфері, та передбачається як дисциплінарна (включаючи матеріальну), цивільно-правова, адміністративна відповідальність, так і кримінальна за вчинення правопорушень в інформаційній сфері; розроблені та 
діють численні закони та підзаконні акти, які регулюють інформаційні відносини.

При цьому, практичне застосування таких законів досить слабке, оскільки відсутні конкретні механізми і дотримання законодавства на практиці, зокрема у зв'язку 3 недосконалістю понятійно-категоріального апарату [5, с. 72]. Слід визначити поняття інформаційного правопорушення 3 метою чіткого відмежування видів відповідальності за їх вчинення.

Проблематика юридичної відповідальності завжди посідала одне із центральних місць у юридичній науці. У сучасній юридичній доктрині найбільш поширеним $є$ поділ юридичної відповідальності на чотири види: кримінальну, цивільну, адміністративну та дисциплінарну. Однак нині все більше вчених схиляються до думки, що така диференціація не $\epsilon$ вичерпною та не відповідає сучасним правовим реаліям. Зокрема, становлення й розвиток нового виду юридичної відповідальності - інформаційноправової [6, с. 55].

У свою чергу, введення нового виду юридичної відповідальності як інформаційно-правова зобов'язує внесення ряду змін до положень нормативно-правових актів та чіткого визначення такого виду відповідальності. На теперішній час виділяють такі види відповідальності як кримінальна, цивільна, адміністративна та дисциплінарна. Новий вид відповідальності потребує обгрунтування щодо необхідності його введення як новий вид відповідальності.

О. М. Селезньова "Концепти розуміння сутності та ознак правопо- рушення в інформаційній сфері" (2017 рік) надала визначення терміну “правопорушення в інформаційній сфері" як вид соціального конфлікту проявляє себе як шкідливе або небезпечне діяння (дія або бездіяльність), вчинене деліктоздатною особою, що посягає на інформацію, інформаційні права (свободи), стан інформаційної безпеки держави й певні майнові блага шляхом застосування інженернотехнічних та інформаційнокомп'ютерних технологій або без такого застосування, але завжди пов'язане 3 інформаційним середовищем [7, с. 144]. Слід акцентувати увагу, що спосіб вчинення інформаційних правопорушень може полягати у застосуванні інформаційних технологій та без їх застосування, але це завжди пов'язане зі світом інформації.

У свою чергу, Л. П. Коваленко проведено грунтовне дослідження, яке пов'язане з ознаками кримінальних правопорушень в інформаційній сфері. У праці “Деякі питання щодо правопорушень в інформаційній сфері" (2013 р.) зазначено, що до ознак кримінального правопорушення належить діяння, протиправність, суспільна небезпека, винність, караність. Встановлено, що діяння $\epsilon$ усвідомленими особою актами поведінки, які виражені як у діях, так і в бездіяльності, та можуть вважатися інформаційним правопорушенням; протиправність полягає у порушенні правил поведінки, встановлених відповідними правовими нормами; суспільна небезпека посягає на врегульовані законами суспільні відносини, які виникають та існують при здійсненні інформаційної діяльності; винність як 
ознака існує у випадках, коли має місце вина у формі умислу або необережності; караність являє собою відповідальність за вчинення інформаційного правопорушення [8].

Відсутність будь-якої з ознак кримінального правопорушення тягне за собою відсутність кримінального правопорушення, для формування складу необхідна наявність всіх ознак та складових елементів. Детальне дослідження інформаційних кримінальних правопорушень необхідне для формування понятійного апарату цієї категорї̈ діянь.

Д. О. Маріц “Склад правопорушення в інформаційній сфері” (2018 р.) визначив, що юридичним складом кримінального правопорушення $\epsilon$ сукупність таких обставин як: 1) поширення недостовірної та/або негативної інформації про особу у будь-який спосіб, форму; 2) поширена інформація стосується позивача; 3) поширена інформація порушує права позивача; 4) відмова, несвоєчасність надання інформації перешкоджає або унеможливлює особі реалізувати свої об'єктивні права; 5) будь-які неправомірні дії або бездіяльність, пов'язані з оборотом інформації в суспільстві, завдають, як майнової, так і немайнової шкоди особі [9, с. 101].

Ми погоджуємось 3 науковцем, що об'єктивна сторона кримінального правопорушення може торкатись вчинення неправомірних дій або бездіяльності, які наносять шкоду.

0. О. Тихомиров у науковій статті “Інформаційний делікт як підстава “інформаційної” юридичної відповідальності: відмітні ознаки” (2019 р.) наголошує на тому, що правопорушення в інформаційній сфері набули системного характеру та визначаються науковцем як найнебезпечніше для держави явище. Ідеї “інформаційної” юридичної відповідальності мають скласти здобутки інформаційної деліктології, а подальша юридична обробка і прагматизація вже набутих знань повинні стати основою удосконалення комплексного інституту юридичної відповідальності в інформаційній сфері як фундаментального правового засобу, механізму, гаранту, покликаного забезпечувати регулятивну, захисну і охоронну дієвість інформаційного права, без чого неможливе існування й розвиток сучасного громадянського та інформаційного суспільства [10, с. 37]. Системність вчинення кримінальних правопорушень вказує на те, що суб'єкти їх вчинення вдосконалюють свої знання та навички у зазначеній сфері.

У статті “Підстави юридичної відповідальності в інформаційній сфері" (2017 р.) авторства Г. М. Писаренко вказується на те, що необхідно створити Інформаційний кодекс, який допоможе у визначенні єдиного підходу до відповідальності за вчинення інформаційних правопорушень. Науковець зазначає, що загалом юридична відповідальність відноситься до складних тем сучасної юридичної науки та потребує єдності думок теоретиків та практиків [11, с. 18]. Ми погоджуємось, що доцільно розробити новий комплекс рекомендацій по вдосконаленню законодавства у сфері попередження та розкриття інформаційних кримінальних правопорушень, але не обов'язково створювати для цього питання окремий кодекс.

О. Косиця "Актуальні питання вдосконалення законодавства у 
сфері протидії кіберзлочинності" (2017 р.) запропонувала ввести в національне законодавство та надати визначення наступних термінів: кіберпростір, кібертероризм, кіберекстремизм, кібервійни, кіберзлочин, кіберзлочинність; встановити перелік кримінальних правопорушень, які відносяться до інформаційних; створити комплекс організаційно-правових та технічних заходів протидії правопорушенням, використовуючи досвід розвинених країн та спеціалістів у сфері IT; розробити систему взаємодії та координації під час розслідування інформаційних правопорушень [12, с. 83].

Слід зазначити, що зі швидкоплинним розвитком інформаційних технологій деякі терміни потребують наукового уточнення, але вони повинні становити єдину та цілу картину, фактично гармонічно відтворювати своє визначення.

Висновки. Опрацювавши викладений матеріал, слід зазначи- ти, що під інформаційним правопорушенням розуміють протиправну, винну (умисну або необережну) дію чи бездіяльність конкретного суб'єкта, що здійснює замах на встановлений інформаційний правопорядок i заподіює шкоду інформаційній сфері або створює реальну загрозу такого спричинення і за яку законом передбачено юридичну відповідальність. Відповідно законодавцем визначено, що інформаційне правопорушення має свої об'єктивні та суб'єктивні ознаки. Тільки за умови існування всіх ознак таке правопорушення буде існувати, а особу, яка його вчинила можуть притягти до відповідальності.

Доцільно наголосити, що інформація потребує додаткового захисту від несанкціонованих втручань, законодавством визначена пряма заборона вчинення незаконних дій з інформацією.

\section{Список використаних джерел}

1. Конституція України Відомості Верховної Ради України (ВВР). 1996. № 30. Ст. 141.

2. Про доступ до публічної інформації: Закон України від 13.01.11 р. № 2939VI. Відомості Верховної Ради України (ВВР). 2011. № 32. Ст. 314.

3. Стратегія розвитку інформаційного суспільства в Україні: Розпорядження Кабінету Міністрів України від 15.05.13 р. № 386-р. Офіційний вісник України. 2013. № 44. Ст. 1581.

4. Пахомова I.А. Юридична відповідальність державних службовців за правопорушення у сфері обігу інформації. Вісник Харківського національного університету імені В. Н. Каразіна. 2016. №21. С. 85-89.

5. Волкова А. О. Особливості юридичної відповідальності за правопорушення в інформаційній сфері. Правова інформатика. 2014. №1. С. 72-80.

6. Селезньова О.М., Руданець В. В. Концепти розуміння сутності та ознак правопорушення в інформаційній сфері. Право і суспільство. 2017. №3. С. 142-145.

7. Писаренко Г.М. Підстави юридичної відповідальності в інформаційній сфері. Держава та регіони. 2017. №2. С. 14-18.

8. Коваленко Л.П. Деякі питання щодо правопорушень в інформаційній сфері. Форум права. 2013. №4. С. 158-167. 
9. Маріц Д.О. Склад правопорушення в інформаційній сфері. Юридичний науковий електронний журнал. 2018. №4. С. 98-101.

10. Тихомиров О.О. Інформаційний делікт як підстава “інформаційної” юридичної відповідальності: відмітні ознаки. Інформація і право. 2019. №1. С. 37-44.

11. Писаренко Г.М. Юридична відповідальність в інформаційній сфері: окремі аспекти становлення. Науковий вісник Ужгородського національного університету. 2016. №36. С. 55-58.

12. Косиця О. Актуальні питання вдосконалення законодавства у сфері протидії кіберзлочинності. Теорія і практика. 2017. №2. С. 81-84.

\section{References}

Pakhomova, I. A. (2016). Yurydychna vidpovidal'nist' derzhavnykh sluzhbovtsiv za pravoporushennia u sferi obihu informatsii. Visnyk Kharkivs'koho natsional'noho universytetu imeni V. N. Karazina. 21, 85-89.

Volkova, A. O. (2014). Osoblyvosti iurydychnoi vidpovidal'nosti za pravoporushennia v informatsijnij sferi. Pravova informatyka, 1, 72-80.

Selezn'ova, O. M. (2017). Kontsepty rozuminnia sutnosti ta oznak pravoporushennia v informatsijnij sferi. Pravo i suspil'stvo, 3, 142-145.

Pysarenko, H. M. (2017). Pidstavy iurydychnoi vidpovidal'nosti v informatsijnij sferi. Derzhava ta rehiony, 2, 14-18.

Kovalenko, L. P. (2013). Deiaki pytannia schodo pravoporushen' v informatsijnij sferi. Forum prava, 4, 158-167.

Marits, D. O. (2018). Sklad pravoporushennia v informatsijnij sferi. Yurydychnyj naukovyj elektronnyj zhurnal, 4, 98-101.

Tykhomyrov, 0. 0. (2019). Informatsijnyj delikt iak pidstava “informatsijnoi” iurydychnoi vidpovidal'nosti: vidmitni oznaky. Informatsiia i pravo, 1, 37-44.

Pysarenko, H. M. (2016). Yurydychna vidpovidal'nist' v informatsijnij sferi: okremi aspekty stanovlennia. Naukovyj visnyk Uzhhorods'koho natsional'noho universytetu, 36, 5558.

Kosytsia, 0. (2017). Aktual'ni pytannia vdoskonalennia zakonodavstva u sferi protydii kiberzlochynnosti. Teoriia i praktyka, 2, 81-84.

G. Muliar, Doctor of Laws, associate Professor, professor of Criminal Law, Procedure and Criminology of the Academy of Labor, Social Relations and Tourism

ORCID: 0000-0003-2636-0509

o. Hovpun, Doctor of Law, associate Professor, нead of the Department of Criminal Law, process and criminology of the Academy of Labor, social relations and tourism ORCID: 0000-0002-5753-966X

A. Begma, PhD in Law, associate professor of the department of criminal law, process and criminalistics academy of Labour of Social Relations and Tourism

ORCID: 0000-0003-3009-2850

\section{Peculiarities of personal criminal liability in information}

The article considers some problematic issues of bringing to criminal responsibility for committing information offenses. The definition of such terms as information offense, information responsibility is investigated. It is expedient to intro- 
duce new terms into the legislation on information offenses: cyberspace, cyberterrorism, cyber extremism, cyberwar, cybercrime, cybercrime and provide them with definitions. The legislation defines four types of liability: criminal, administrative, civil, disciplinary.

The strategy for the development of the information society in Ukraine has defined the basic principles of the information society, including: the legality of obtaining, using, disseminating, storing and protecting information; information security.

Information needs additional protection against unauthorized interference, the law explicitly prohibits illegal actions with information. The protection of information is an important task of national security, as the place and role of any state in the international community is related to its ability to produce, consume and use new knowledge and technologies.

An information offense is an illegal, culpable (intentional or negligent) act or omission of a specific entity that encroaches on the established information order and causes damage to the information sphere or creates a real threat of such causing and for which the law provides for legal liability. The legal composition of a criminal offense is a set of circumstances such as: 1) dissemination of unreliable and/or negative information about the person in any way, form; 2) the disseminated information concerns the plaintiff; 3) the disseminated information violates the rights of the plaintiff; 4) refusal, late provision of information prevents or makes it impossible for a person to exercise his objective rights; 5) any illegal actions or omissions related to the circulation of information in society, cause both property and non-property damage to the person.

Keywords: information offense; information and legal responsibility; cybercrime. 